\title{
Olive ridley inter-nesting and post-nesting movements along the Brazilian coast and Atlantic Ocean
}

\author{
Erik A. P. Santos ${ }^{1, *}$, Augusto C. C. D. Silva ${ }^{2}$, Roberto Sforza $^{1}$, Fabio L. C. Oliveira ${ }^{2}$, \\ Marilda I. Weber ${ }^{2}$, Jaqueline C. Castilhos ${ }^{2}$, Maria López-Mendilaharsu' ${ }^{2}$, \\ Maria A. A. G. Marcovaldi' ${ }^{2}$, Renata M. A. $\operatorname{Ramos}^{3}$, Andrew DiMatteo ${ }^{4,5}$ \\ ${ }^{1}$ Centro TAMAR-ICMBio, Vitória, Espírito Santo, CEP 29050-335, Brazil \\ ${ }^{2}$ Fundação PRÓ-TAMAR, Salvador, Bahia, CEP 48280-000, Brazil \\ ${ }^{3}$ Engeo Soluções Integradas Ltda, Vitória, Espírito Santo, CEP 29066-040, Brazil \\ ${ }^{4}$ CheloniData LLC, Berthoud, Colorado 80513, USA \\ ${ }^{5}$ Present address: McLaughlin Research Corporation, Middletown, Rhode Island 02842, USA
}

\begin{abstract}
The states of Sergipe and Bahia comprise the main nesting beaches for olive ridley sea turtles Lepidochelys olivacea in Brazil. Between February 2014 and March 2015, 40 L. olivacea were equipped with Argos platform transmitter terminal tags. A state-space model was applied to Argos location data to investigate the animals' spatial ecology and identify areas of restricted movements (ARMs) and directional movements. The inter-nesting ARMs included the continental shelf from the south of Alagoas state to the north of Bahia, totaling $7244 \mathrm{~km}^{2}$ (kernel density estimation, $90 \%$ isopleth) and generally extended up to $22 \mathrm{~km}$ from the coast or to the $50 \mathrm{~m}$ isobath. The post-nesting directional movements were classified as either (1) neritic north/ northeastern (N/NE) Brazil to French Guiana ( $\mathrm{n}=4$ turtles), (2) neritic south/southeastern (S/SE) Brazil $(n=16)$, or (3) oceanic $(n=19)$ from Brazil to West Africa. ARMs consistent with foraging areas were identified for 24 olive ridleys: 15 along the continental shelf of SE Brazil, 2 adjacent to Ceará and Maranhão states (between the 25 and $75 \mathrm{~m}$ isobaths), and 7 off the African countries of Cape Verde, Senegal, Gambia, Guinea-Bissau, and Sierra Leone. The results demonstrated the complexity of olive ridley movements from northern Brazil, raised questions about connectivity, and highlighted threats such as fisheries, ports, and hydrocarbon exploration fields overlapping with, or near to, high-use areas. These results can be used as a basis for spatial management measures to protect this endangered species.
\end{abstract}

KEY WORDS: Satellite tracking · Lepidochelys olivacea · Inter-nesting area · Migratory corridors · Spatial ecology

\section{INTRODUCTION}

Olive ridley turtles Lepidochelys olivacea (Eschscholtz, 1829) are the most abundant marine turtle species (Abreu-Grobois \& Plotkin 2008), with widespread distribution in tropical and subtropical oceans, except for the Gulf of Mexico. Despite their wide distribution and abundance, olive ridleys are among the least studied species in terms of satellite-tracking, with a total of 25 publications, a number higher only than that for Kemp's ridley L. kempii $(\mathrm{n}=18)$ and that

${ }^{*}$ Corresponding author: erik.santos@icmbio.gov.br for flatback turtles Natator depressus $(\mathrm{n}=4)$, both of which have more restricted distributions (Jeffers \& Godley 2016).

Globally, olive ridleys exhibit greater plasticity of behavior and habitats than other marine turtles. Their habitats may be mainly neritic, as recorded from breeding areas located in Australia (McMahon et al. 2007, Whiting et al. 2007, Hamel et al. 2008), Oman (Rees et al. 2012), French Guiana (Plot et al. 2015, Chambault et al. 2016), and Brazil (Silva et al. 2011), or oceanic, as seen in Costa Rica (Plotkin 2010), India

(C) The authors 2019. Open Access under Creative Commons by Attribution Licence. Use, distribution and reproduction are unrestricted. Authors and original publication must be credited. 
(Ram et al. 2009), and Gabon/Angola (Maxwell et al. 2011, Pikesley et al. 2013).

This species is subject to threats such as dredging (Goldberg et al. 2015), vessel collision, and high bycatch rates by coastal fisheries within breeding and foraging areas (Gopi \& Pandav 2006, Silva et al. 2010, Casale et al. 2017, Guimarães et al. 2018), or during oceanic movements (Sales et al. 2008). In Brazil, the main threat to olive ridleys is bycatch and mortality associated with shrimp trawling. This fishery occurs intensely along the continental shelf and adjacent to nesting beaches (Silva et al. 2010, 2011, Guimarães et al. 2018). Along these nesting beaches, a large number of olive ridley strandings have been recorded, and efforts are underway to reduce incidental mortality (Silva et al. 2010). The main olive ridley nesting area in Brazil is located in the NE of the country, on the coast of Sergipe state and to the north of Bahia state (between $10.5^{\circ}$ and $12.5^{\circ} \mathrm{S}$ ). Nesting activity has also been recorded on the beaches of Espírito Santo state, in the SE region of Brazil.

The nesting season occurs primarily during the austral summer, from September to March, although occasional nesting is observed in all months of the year (Silva et al. 2007). Despite the recorded strandings, the number of nests per year for this species in Brazil shows an increasing trend. This is attributed to the conservation strategy implemented over the last 3 decades (Silva et al. 2007). The Brazilian National Action Plan for the Conservation of Sea Turtles (Santos et al. 2011) establishes the identification and protection of high-use areas for sea turtles as a conservation priority. Among the available techniques to assess the spatial-temporal distribution of animals, including high-use areas and range of migration strategies, satellite telemetry tracking has become a standard tool (Godley et al. 2008, Wilmers et al. 2015). To date, only 1 study using satellite telemetry has been performed on olive ridleys in Brazil (Silva et al. 2011). The 10 females tracked by Silva et al. (2011) from nesting beaches in Sergipe highlighted postreproductive migration to neritic foraging areas along the Brazilian coast, as well as oceanic movements for 2 animals. That study also showed the overlap between satellite tracks and fishing areas, mainly neritic shrimp trawling and oceanic longliners, highlighting the potential of satellite telemetry to identify threats and support management strategies (Silva et al. 2011).

The objectives of the present study were to (1) identify inter-nesting area(s), post-nesting migration strategies, and foraging areas for olive ridleys from the main breeding area in Brazili (2) improve knowl- edge on the ecology of this species; and (3) propose alternatives for conservation in the Atlantic Ocean.

\section{MATERIALS AND METHODS}

\subsection{Study site}

The Pirambu beaches, located in the northern portion of the state of Sergipe, Brazil, can be characterized as high energy, with a narrow continental shelf, in the tropical zone, with warm temperatures and a dry summer. These beaches comprise the main reproductive site of Lepidochelys olivacea in Brazil, with nesting of loggerheads Caretta caretta and hawksbills Eretmochelys imbricata occurring regularly as well. Sporadic nests of green turtles Chelonia mydas are also recorded (Silva et al. 2007).

The importance of this area for the reproduction of sea turtles led the Brazilian government to create the Santa Isabel Biological Reserve in 1988. This protected area has the objective of maintaining the natural characteristics of coastal environments and associated biological processes in the area and covers approximately $40 \mathrm{~km}$ of sea turtle nesting beaches (Fig. 1).

\subsection{Tag deployment}

We deployed 40 platform terminal transmitters (PTTs) on olive ridley sea turtles nesting along the Pirambu beach. Two PTT models were used: SPOT293A ( $\mathrm{n}=18)$ and SPLASH10-F-296A $(\mathrm{n}=22)$, both manufactured by Wildlife Computers ${ }^{\odot}$.

Night patrols to capture olive ridleys occurred over $31 \mathrm{~km}$ of beaches located between $36.847^{\circ} \mathrm{W}, 10.734^{\circ} \mathrm{S}$ and $36.605^{\circ} \mathrm{W}, 10.582^{\circ} \mathrm{S}$. The deployments occurred between 14 January 2014 and 14 January 2015. Prior to PTT attachment, individuals were measured and classified into 3 size classes based on curved carapace length $(\mathrm{CCL})$ : small $(\mathrm{CCL} \leq 68 \mathrm{~cm})$, medium (CCL 69-73 cm), and large (CCL $\geq 74 \mathrm{~cm})$. The PTT attachment took place at the Pirambu TAMAR base. The attachment protocol consists of cleaning the second and third medial scutes of the carapace and attaching the satellite tag with Tubolit ${ }^{\circledR}$ epoxy and fiberglass. The SPLASH tags were initially protected with a Propspeed anti-fouling coat. The full attachment was then coated with anti-fouling paint (International Yacht Paint) and allowed to dry for $60 \mathrm{~min}$ before turtles were released. Inconel tags (National Band and Tag) were attached to the trailing edge of each front flipper following Balazs (1999). 

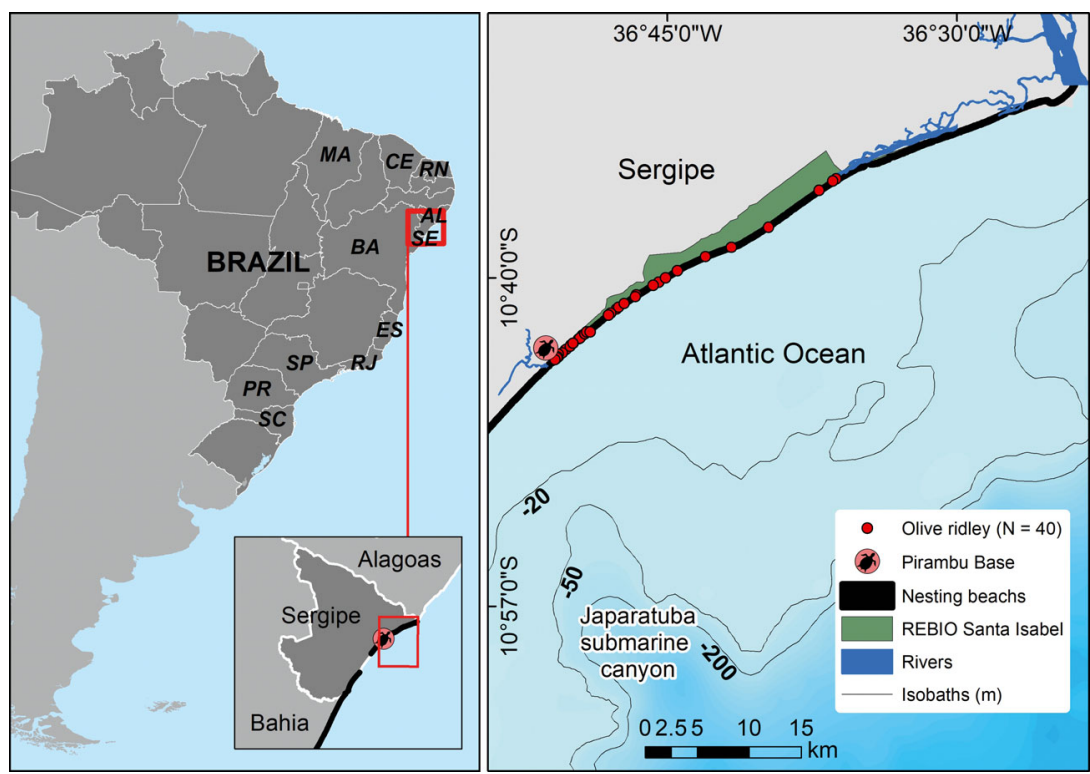

Fig. 1. Right: primary olive ridley nesting beaches in Brazil and locations of tagged sea turtles along the Pirambu beach and Santa Isabel Biological Reserve (REBIO). Left: the Brazilian coastal states of Maranhão (MA), Ceará (CE), Rio Grande do Norte (RN), Alagoas (AL), Sergipe (SE), Bahia (BA), Espírito Santos (ES), Rio de Janeiro (RJ), São Paulo (SP), Paraná (PR), Santa Catarina (SC)

subsequent SSM smoothed the tracks into even time intervals. In addition to the Douglas filter, both GPS and Argos locations were removed if they fell on land. The first $48 \mathrm{~h}$ of post-deployment locations were removed to account for any behavioral changes associated with tagging and release. Class Z Argos locations were also removed. Lastly, tracks were examined to determine if gaps greater than $1 \mathrm{wk}$ occurred between subsequent points, in which case the 2 track segments were analyzed separately to avoid over interpolation of locations.

A modified version of the statespace switching model first introduced by Jonsen et al. (2005), and using code from Breed et al. (2009), was applied to all Argos and GPS locations. The code from Breed et al. (2009) was modified by creating additional error classes for GPS data based on circular error described by

The SPOT and SPLASH tags were configured for continuous collection of location data (no duty cycle). To acquire more accurate localization signals (Fastloc GPS), SPLASH tags were configured to obtain 1 GPS location per hour. All data were transmitted via the Argos system (www.argos-system.org), and the tracking information was automatically downloaded using the Satellite Tracking and Analysis Tool (STAT; Coyne \& Godley 2005). The decoding of GPS locations collected by the SPLASH transmitters was accomplished using the Wildlife Computers ${ }^{\circledR}$ DAPProcessor software.

\subsection{Switching state-space model (SSM)}

An SSM was used to gain inference on animal behavior and smooth the satellite tracks into equal time intervals. Prior to the application of the SSM, all locations were filtered with the Douglas filter (Douglas et al. 2012) in Movebank (Wikelski \& Kays 2015) to remove unrealistic Argos locations. GPS locations were treated as equivalent to Argos location class 3 for the purpose of the Douglas filter. Douglas filter parameters were selected based on criteria established by the Turtle Expert Working Group for hardshell turtles (TEWG 2009) and included filters for speed and turn angle. A best daily location was not selected, as the
Bryant (2007) and subsequently combining GPS and Argos locations in the SSM. The selected model was originally developed for seals but is also applicable to marine turtles (Hart et al. 2013).

The SSM was run using R (R Core Team 2015) and WinBugs (Thomas 1994). We used $6 \mathrm{~h}$ as the time interval to smooth the track, as a compromise between detecting meaningful changes in movement modes and model processing time. To reach convergence, 5000 burn-in iterations and 10000 samples were used. SSM diagnostics were examined to ensure that Monte Carlo Markov chains were mixing and that model parameters were converging appropriately.

The model attempted to classify smoothed points into 2 states, an 'area-restricted movement' (ARM) mode, inferred to be either inter-nesting or foraging areas depending on timing and based on the known ecology of marine turtles (see Section 2.4), and a 'directional movement' mode, inferred to represent active migration.

The model produces 2 outputs for predicting behavioral state at each location: a mean and a mode of the total samples. Many studies use the mean values and cutoff thresholds to define one state or the other. Here we used the mode of the prediction to retain as many points as possible for analysis. In general, the turtles showed very distinctive behavioral switching, so we believe this decision to be justifiable. 


\subsection{Home range}

Home ranges in the form of parametric utilization distributions (Worton 1989) for individuals were calculated using the R package 'adehabitat' (Calenge 2006). Home ranges were calculated for the SSM ARM locations using a kernel density estimation (KDE) method. The bandwidth, or smoothing parameter, of the KDE was calculated for each home range using the ad hoc (reference bandwidth, HREF) method (Worton 1989). Surface contours (isopleths) were created from the utilization distributions to measure core use areas, defined as the $50 \% \mathrm{KDE}$, and the full home range, defined as the $90 \% \mathrm{KDE}$.

Based on the available information about the ecology of the species, a distinction between the home ranges was made. The ARM locations near or associated with the reproductive beaches (deployment locations) were used to define inter-nesting area home ranges. ARM locations at the end of tracks, or between segments of migration, were defined as foraging areas. Turtles in this region enter a distinct migration phase after completion of nesting, allowing us to confidently assume that ARM prior to directional movement was in the inter-nesting area (similar to Maxwell et al. 2011), and subsequent ARM areas away from the nesting beaches were assumed to represent foraging activity.

Primary productivity and fishing effort were quantified within the inferred foraging ARM areas. Primary productivity was analyzed using a vertically generalized production model (VGPM; Behrenfeld \& Falkowski 1997), and fishing effort was derived from the 'Daily fishing effort at 100th degree resolution' dataset (Kroodsma et al. 2018). The data were downloaded for the years 2014 to 2016, which correspond to the duration of the present study. These data are available at www.science.oregonstate.edu/ ocean.productivity/index.php and https://globalfishing watch.org, respectively. A 3 yr average for primary productivity and the fishing effort sum was generated in the form of raster layers with a cell size of $32.210 \mathrm{~m}$ for VGPM and $5000 \mathrm{~m}$ for fishing effort that covered the entire study area.

An ANOVA was applied to identify significant variations between the mean values of productivity (VGPM) and fishing effort (fishing hours) within versus outside inferred foraging areas. The mean values of productivity and fishing effort within the combined inferred foraging areas were compared to 10 sets of randomly selected sample areas. Sample areas were generated from hexagons with a diameter of $160 \mathrm{~km}$, or $17000 \mathrm{~km}^{2}$, corresponding to the aver- age size of the foraging ARMs. The hexagons were placed in a regular grid bounded by the distribution of olive ridley tracks in the present study. Hexagons were added at random to the sample until the size of the sample area was approximately $498584 \mathrm{~km}^{2}$, the total area of the inferred foraging ARM home ranges. Heterogeneous mean groups were identified by the Tukey honestly significant difference test (Zar 1999).

\subsection{Inter-nesting residence time and inferred inter-nesting interval}

For the inter-nesting home range area, residence time was defined as the number of days spent in ARM mode (Barraquand \& Benhamou 2008, Seidel et al. 2018). Inferred second nesting events were also evaluated following Maxwell et al. (2011). Given the low satellite coverage in equatorial areas and system limitations that prevent the transmission of all fastloc GPS data collected by the SPLASH PTTs $(\mathrm{N}=22)$, secondary nesting events had to be primarily inferred from on-land or nearshore Fastloc GPS and Argos locations, taking into consideration their location classes. For 2 olive ridleys, second nesting events were confirmed by Fastloc GPS haul outs. The inferred second nesting events were compared to the known duration of the average inter-nesting interval for olive ridleys in Brazil (Matos et al. 2012).

\subsection{Directional movement mode}

In order to identify important migration corridors, a grid of hexagons with a $25 \mathrm{~km}$ diameter was overlaid with locations identified by the SSM as directional movement and inferred to represent migration. This diameter of $25 \mathrm{~km}$ was selected because it best captured the size of the continental shelf in the region (Dominguez et al. 2013), an important bathymetric feature for olive ridley migration. Tracks were aggregated by polygon, and points from individual tracks were weighted by track duration so that tracks with short durations biased the analysis less towards deployment locations. Hexagons with higher values are more important as migratory corridors. This analysis was performed using ArcGIS 10.3 (ESRI 2014).

\section{RESULTS}

Of the 40 olive ridleys, only 1 (PTT 135271) was excluded from analysis because of the premature 
end of transmissions (after $13 \mathrm{~d}$ ). Olive ridley CCLs varied from 64 to $79 \mathrm{~cm}$, with a mean \pm SD of 71.5 $\pm 3.85 \mathrm{~cm}$. The duration of the transmissions ranged from 44 to $431 \mathrm{~d}$, with a mean of $165 \pm 91.2$ d. The average distance traveled per turtle, including ARM and directional movements, was $4577 \pm$ $1918.3 \mathrm{~km}$, with a minimum and maximum of 1286 and $8562 \mathrm{~km}$.

Descriptive parameters for PTT deployments, including the capture and measurement of sea turtles, duration of transmissions, inferred inter-nesting interval, home range areas, duration in days for the different SSM modes (ARM and directional movements), and distances traveled during post-nesting migration are presented in Tables S1 to S4 in Supplement 1 at www.int-res.com/articles/suppl/n040p149_supp/.

\subsection{Inter-nesting period}

Inter-nesting ARM was identified for 29 olive ridleys that stayed in the vicinity of the main nesting beaches. It was possible to infer second nesting events for 20 of those 29 turtles based on satellite locations.

For 10 olive ridleys, the post-nesting migration started immediately after attachment of PTTs and release. From the SSM it was clear when all animals that had an inter-nesting period transitioned to directional movement at the end of nesting.

The sampled population's total inter-nesting area, estimated as the combined $90 \%$ KDE home range used by 29 turtles, comprised the north coast of Bahia, all of the continental shelf off Sergipe, and the southern coast of Alagoas. The size of the combined inter-nesting area was $7244 \mathrm{~km}^{2}$. Although the inter-nesting area was relatively extensive, its core area (KDE 50\%) totaled approximately $1400 \mathrm{~km}^{2}$, which corresponds to $19 \%$ of the total inter-nesting home range area (Fig. 2).

The turtles' residence time in the inter-nesting area ranged from 7 to $34 \mathrm{~d}$, with a mean of $20 \pm 7.6 \mathrm{~d}$. Inferred secondary nesting events occurred on an average of $18 \pm 4.5$ d (range: 9-23 d) from tagging release, with shorter durations possibly associated with a false crawl followed by a re-nesting event.

The combined inter-nesting area derived from ARM locations was adjacent to the main nesting beach for the species in Brazil, comprised depths up to $1000 \mathrm{~m}$, and extended approximately $40 \mathrm{~km}$ from the coast, reaching the continental shelf slope. The greatest depths were associated with a submarine canyon feature, which was used by 11 of the turtles. The core area (KDE $50 \%$ ) was mainly located in shallow waters, as deep as the $50 \mathrm{~m}$ isobath, reaching distances $22 \mathrm{~km}$ from the coast (Fig. S1 in Supplement 1).

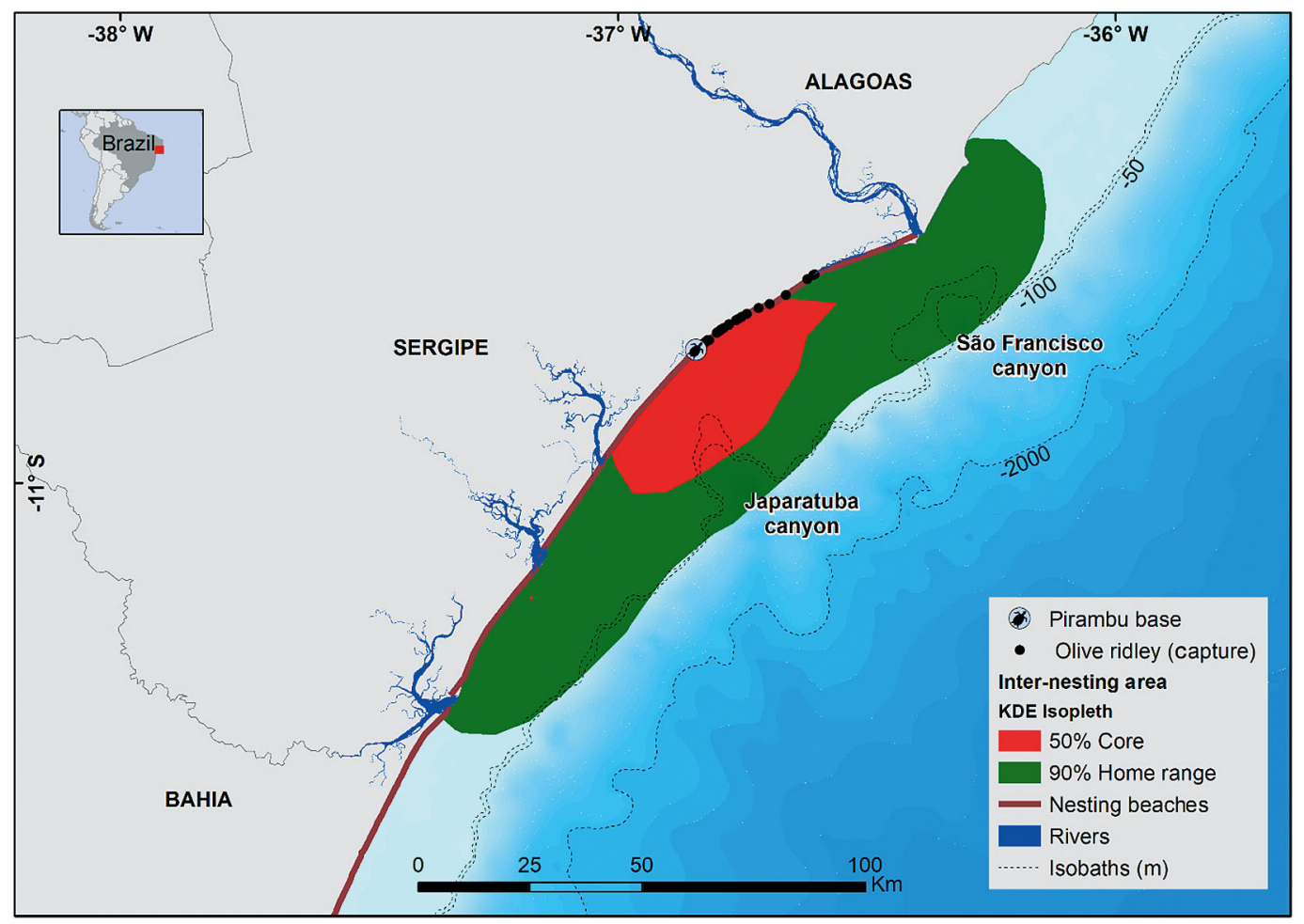

Fig. 2. Olive ridley combined kernel density estimation of the inter-nesting area used by 29 turtles and platform transmitter terminal tag deployment locations $(\bullet)$ 


\subsection{Post-nesting period}

\subsubsection{Directional movements}

Olive ridleys from Brazil showed remarkable variation in their behavior, although classification into 2 main categories was possible: those who traveled and settled along the coast, both to the north $(n=4)$ and to the south ( $\mathrm{n}=16)$, and those with an oceanic migration strategy $(\mathrm{n}=19)$. The oceanic migration strategy included individuals with initial coastal and subsequent oceanic movements $(\mathrm{n}=15)$, and those that moved offshore immediately $(\mathrm{n}=4)$.

For the 24 turtles that concluded their directional movements and began an ARM, which was inferred as foraging (coastal $=17$ turtles and oceanic $=7$ turtles), there was significant variation in the distance traveled and duration of the migration, which was longer for the animals with oceanic movements (Table 1).

The directional movement locations highlighted a migration corridor, which runs along the continental shelf of Brazil, totaling $3370 \mathrm{~km}$ length. The width of the migratory corridor was variable and was associated with the width of the continental shelf (Fig. 3).

The southern migratory corridor, defined by 16 olive ridleys' directional movements, had an average length of $2283 \pm 281.69 \mathrm{~km}$ (range: $1507.18-2606.65 \mathrm{~km}$ ). An average of $50 \pm 7.1 \mathrm{~d}$ (range: $36-61 \mathrm{~d}$ ) passed before animals completed their directional movements. Of the 16 olive ridleys with southern movements, only 1 (PTT 135248) ceased transmission before a switch to ARM.

Of the 23 post-nesting olive ridleys that moved north, 19 showed oceanic directional movements and 4 traveled along the northern coast of South America. The directional movements were concluded for 7 oceanic turtles after traveling an average of $4509 \pm$

Table 1. Descriptive parameters for duration and distance traveled for the 3 olive ridley migration strategies, as well as statistical comparison using the Mann-Whitney $U$-test

\begin{tabular}{|c|c|c|c|c|c|}
\hline \multirow{2}{*}{$\begin{array}{l}\text { Migratory } \\
\text { strategy }\end{array}$} & \multirow[b]{2}{*}{$\mathrm{N}$} & \multicolumn{2}{|c|}{ - Duration (d) } & \multirow[b]{2}{*}{ Max } & \multirow{2}{*}{$\begin{array}{c}U \text {-test } \\
\mathrm{U}=0.00\end{array}$} \\
\hline & & Mean \pm SD & Min & & \\
\hline Coastal & 17 & $49 \pm 7.8$ & 33 & 61 & $\mathrm{p}=0.000006$ \\
\hline \multirow[t]{3}{*}{ Oceanic } & 7 & $109 \pm 24$ & 75 & 142 & \\
\hline & & Distance & $(\mathrm{km})$ & & $U$-test \\
\hline & $\mathrm{N}$ & Mean \pm SD & Min & Max & $U=1.0$ \\
\hline Coastal & 17 & $2226 \pm 349$ & 1338 & 2607 & $\mathrm{p}=0.00015$ \\
\hline Oceanic & 7 & $4509 \pm 984$ & 3442 & 6063 & \\
\hline
\end{tabular}

$984 \mathrm{~km}$ (range: 3442-6063 km) over $110 \pm 24 \mathrm{~d}$ (range: 75-142 d), moving toward different parts of west Africa such as Cape Verde, Senegal, and Sierra Leone. The other 12 turtles ceased transmissions during directional movements with similar trajectories. Two of the 4 neritic turtles ceased directional movement off the Ceará and Maranhão state coasts in northern Brazil, after traveling 1338 and $2260 \mathrm{~km}$ in 33 and $51 \mathrm{~d}$, respectively. The other 2 turtles ceased transmissions off the coast of Ceará, after traveling $1098 \mathrm{~km}$ in $30 \mathrm{~d}$, and off French Guiana, after travelling $3260 \mathrm{~km}$ in $61 \mathrm{~d}$ (Fig. 3).

\subsubsection{Olive ridley class sizes and post-nesting directional movements}

The olive ridleys that migrated along the northern coast of Brazil had intermediate CCLs. Larger animals migrated south, and the smallest turtles traveled to oceanic waters (see the video in Supplement 2 at www.int-res.com/articles/suppl/n040p149_supp/). The relationship between CCL and migration strategy was significant (ANOVA, $F=22.77$, df $=36$, $\mathrm{p}<$ 0.0001 ) with a heterogeneous group formed by the largest olive ridleys that migrated to the south.

The distinct migration strategies also varied by the time period in which they were observed. Southward, coastal post-nesting migrations made by the largest turtles started only between the months of September and March. Turtles began migrating to coastal areas in the north and to oceanic waters throughout the year (Fig. 4).

\subsubsection{Foraging ARMs}

The SSM identified the transition from directional movement behavior to ARM in 24 of the 40 tagged turtles. The core sizes (50\% KDE) of the coastal and oceanic inferred foraging areas did not show significant differences (Mann-Whitney $U$-test, median coastal: $3442.04 \mathrm{~km}^{2}$, median oceanic: $3898.12 \mathrm{~km}^{2}$, $\mathrm{p}=0.391)$. However, high variability was observed among individuals (mean $\pm \mathrm{SD}: 5654 \pm 5903 \mathrm{~km}^{2}$, range: $35-24795 \mathrm{~km}^{2}$ ).

The combined ARM home range area identified in SE Brazil comprised almost the entire continental shelf adjacent to the states of Rio de Janeiro, São Paulo, Paraná, and the northern portion of Santa Catarina, totaling $114527 \mathrm{~km}^{2}$ (KDE 90\%, n = 15 olive ridleys combined). The core of this area (KDE 50\%) was $22523 \mathrm{~km}^{2}$ and comprised the middle portion of the 


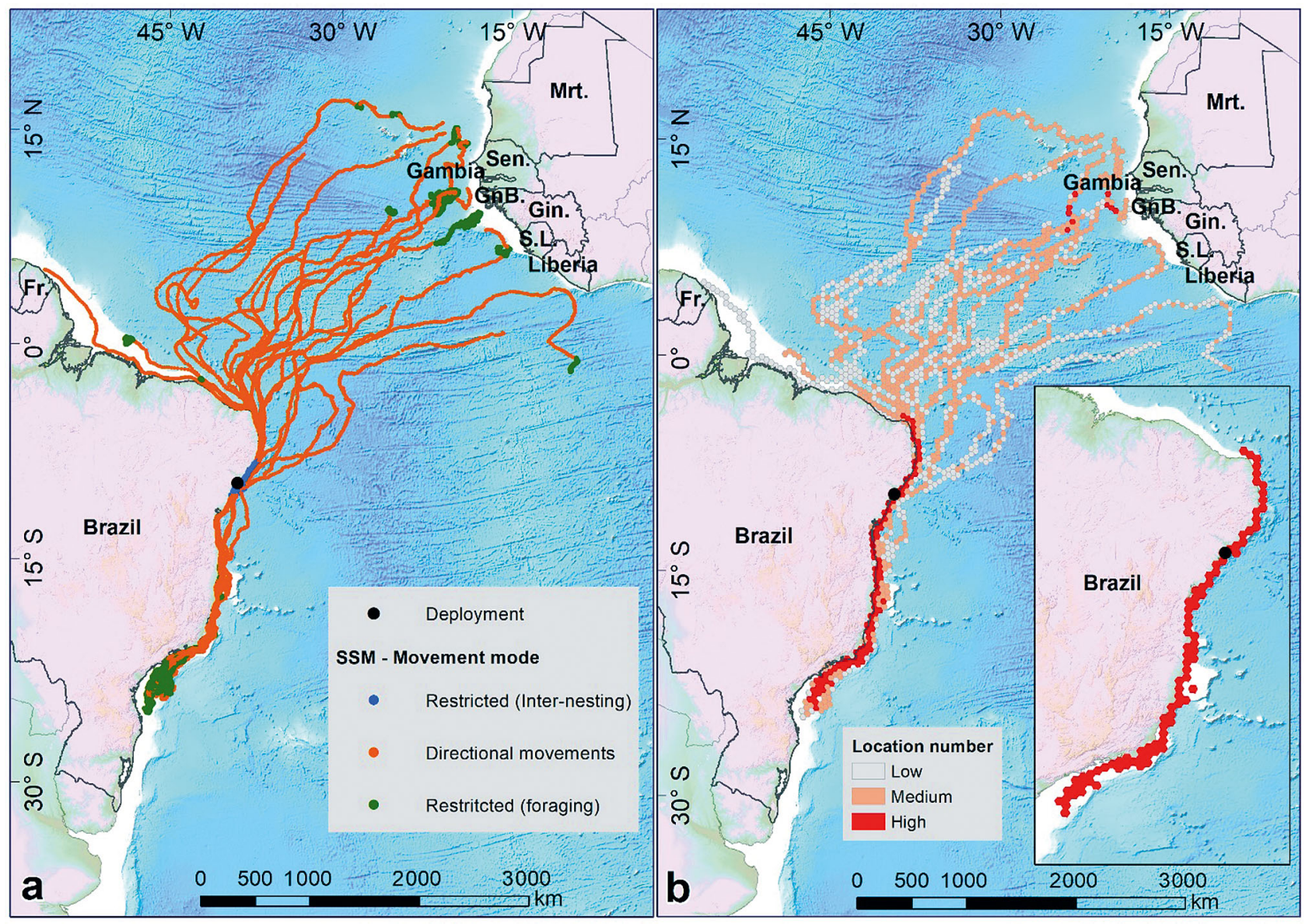

Fig. 3. Olive ridley post-reproductive displacement. (a) State-space model predicted behavior; (b) weighted point density per $25 \mathrm{~km}$ hexagon. Continuous high-density areas along the Brazilian continental shelf indicate a migratory corridor. Fr.: French Guiana, Mrt.: Mauritania, Sen.: Senegal, GnB.: Guinea Bissau, Gin.: Guinea, S.L.: Sierra Leone

continental shelf off São Paulo, between the 25 and $150 \mathrm{~m}$ isobaths, ranging around 40 to $160 \mathrm{~km}$ from the coast (Fig. 5, and see Fig. S2 in Supplement 1).

The 2 neritic ARM areas identified in NE Brazil were situated off the coast of Ceará (core area $35 \mathrm{~km}^{2}$ ), about 35 to $40 \mathrm{~km}$ from the coast and between the 20 and $50 \mathrm{~m}$ isobaths, and off Maranhão state (core area $437 \mathrm{~km}^{2}$ ) about 130 to $155 \mathrm{~km}$ from the coast and between the 50 and $100 \mathrm{~m}$ isobaths (Fig. 6).

The 7 oceanic ARM areas showed a wide variation in size (core KDE range: $1370-24794 \mathrm{~km}^{2}$ ) and location. One ARM was near the archipelago of Cape Verde, 5 were along the Cape Verde basin, off the coasts of Senegal, Gambia, Guinea-Bissau, Guinea, and Sierra Leone, and 1 ARM area was off Liberia and Ivory Coast. Of these olive ridleys, the area used by PTT 140731 was the largest identified in this study, located near the Sierra Leone Rise and overlapping the edge of the continental shelf of Guinea Bissau (Fig. 7).

The southern and oceanic inferred foraging ARMs showed a partial overlap with significantly high pri- mary productivity and fishing effort areas, when compared to the sets of randomly selected sample areas (fishing effort ANOVA, $F=8.567, \mathrm{df}=10$, $\mathrm{p}<0.0001$; VGPM ANOVA, $F=7.8186, \mathrm{df}=10$, $\mathrm{p}<0.0001$; see Figs. S3 \& S4 in Supplement 1).

Similarly, the end point of the turtles' tracks, including the ones without ARM inferred foraging, overlapped with areas of high fishing effort. This was particularly evident within the equatorial Atlantic, along the turtles' displacements to west Africa and on the continental shelf of French Guiana (Figs. S5 \& S6 in Supplement 1).

\section{DISCUSSION}

\subsection{Inter-nesting period}

Lepidochelys olivacea residence times within the inter-nesting area (mean $20 \pm 7.6 \mathrm{~d}$, range $7-34 \mathrm{~d}$ ) and the inferred second nesting intervals (mean $18 \pm$ 
$4.5 \mathrm{~d}$, range 9-23 d) were similar to the inter-nesting intervals previously identified for this species in Brazil, with shorter intervals possibly associated with a false crawl followed by a re-nesting event (Matos et al. 2012).

The duration of the inter-nesting interval is also similar to observations for olive ridleys in other regions, such as Australia (12-23 d, Whiting et al. 2007; 18 and 27 d, Hamel et al. 2008), Gabon and Republic of the Congo (9-25 d, Maxwell et al. 2011), French Guiana (18-39.8 d, Plot et al. 2012), and Oman (17-30 d, Rees et al. 2012).

The core inter-nesting area, mainly out to the $50 \mathrm{~m}$ isobath, can be characterized as a complex ecosystem, in which the mud bottom (67\%) is permeated by sands $(29 \%)$, gravel, and reef environment. This area is the head of a submarine canyon (Neves et al. 2005, Fontes et al. 2017). During the summer, when olive ridley nesting occurs, cooler, nutrient-rich ocean water has been recorded moving on to the continental shelf through the canyon, which affects the demersal fauna in the area (Paes et al. 2007).

We posit that the concentration of olive ridleys in this area, including the submarine canyon, is associ-

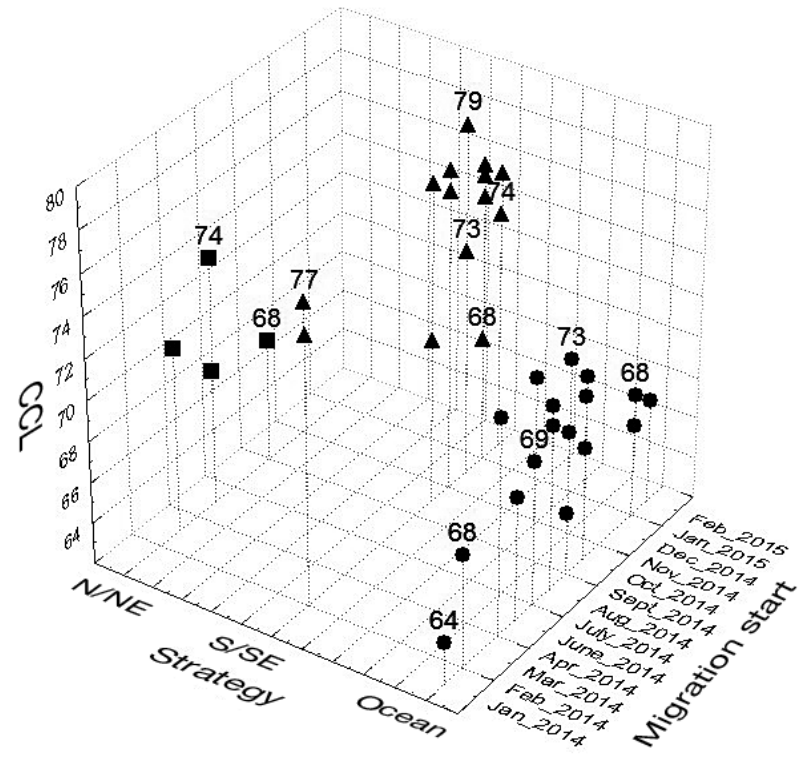

Fig. 4. Post-nesting migration strategies (square: coastal N/NE; triangle: coastal S/SE, circle: oceanic) by month when migration started, and curved carapace length $(\mathrm{CCL}, \mathrm{cm})$

ated with the diversity of features, bottom types, and abundance of resources and refuge. This area contains potential hazards, such as a port terminal with

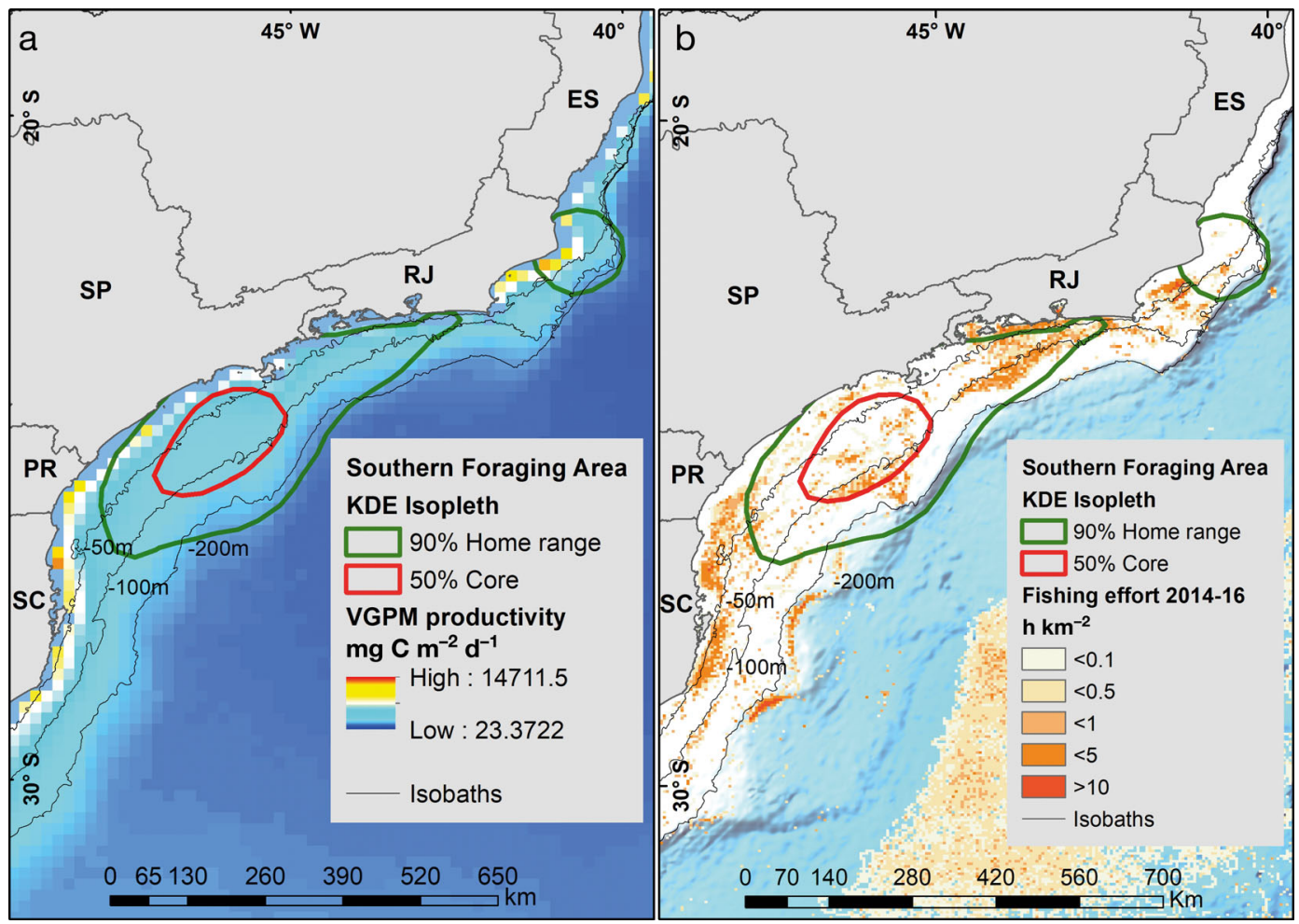

Fig. 5. Southeastern Brazil continental shelf olive ridley foraging area. The kernel density estimation (KDE) combines the state-space model (SSM) foraging behavior locations of 15 turtles that showed similar dispersal strategies. (a) Vertically generalized production model (VGPM) primary productivity mean (2014 to 2016). (b) Hours of fishing effort $\mathrm{km}^{-2}$ (2014 to 2016). Brazilian states: ES: Espírito Santo, RJ: Rio de Janeiro, SP: São Paulo, PR: Paraná, SC: Santa Catarina 


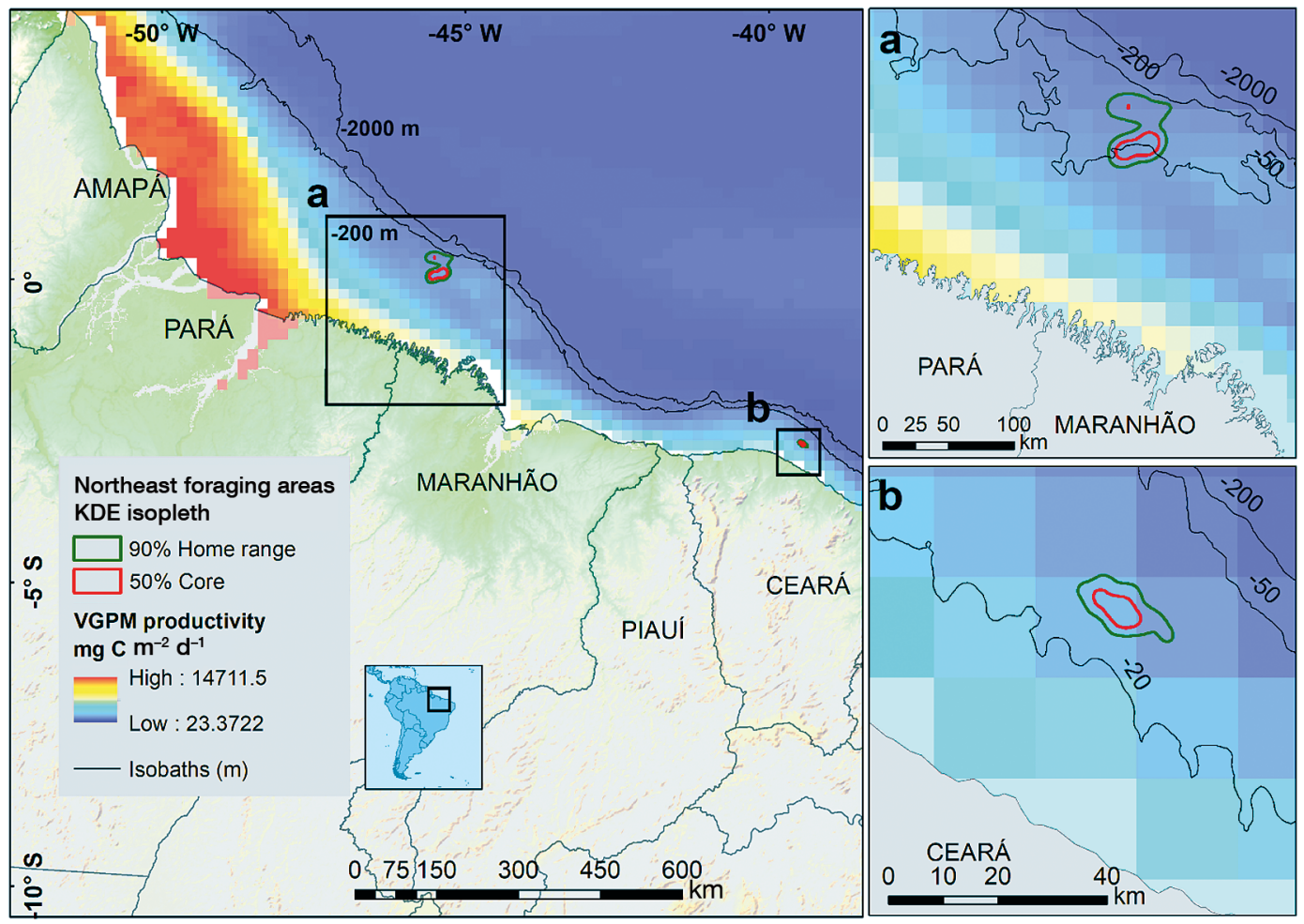

Fig. 6. Primary productivity off the coast of Brazil, with northeastern neritic foraging areas of olive ridley turtles indicated by squares: (a) off the coast of Maranhão state and (b) off Ceará state. KDE: kernel density estimation, VGPM: vertically generalized production model
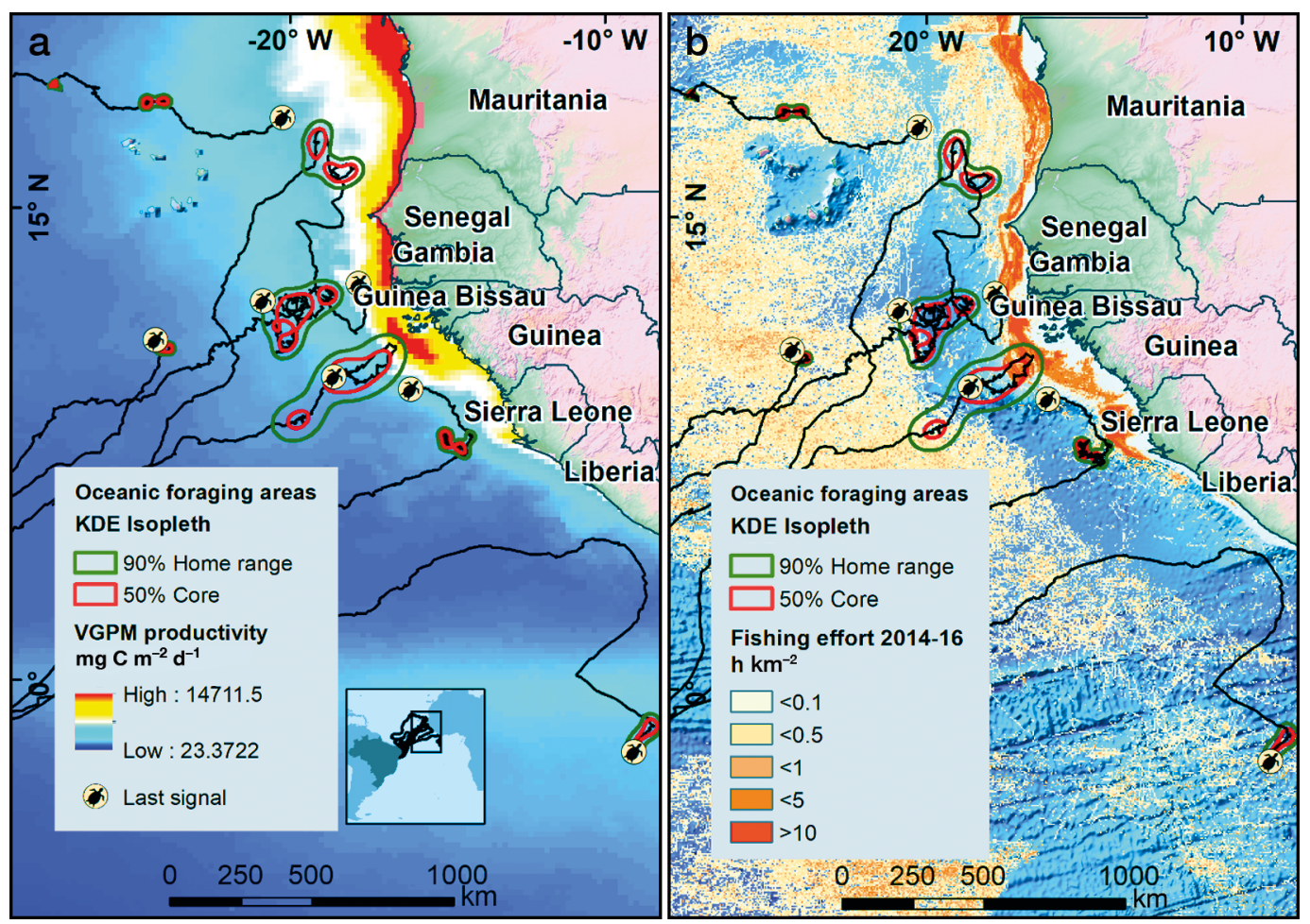

Fig. 7. Olive ridley oceanic foraging areas in west Africa and the overlap with (a) primary productivity (vertically generalized production model, VGPM) and (b) fishing effort in $\mathrm{h} \mathrm{km}^{-2}$. KDE: kernel density estimation 
associated vessel traffic and dredging activities, as well as shrimp trawling, which is implicated in olive ridley strandings along the nesting beaches (Silva et al. 2011). Considering the impacts, a portion of the core area could be converted into a marine protected area, as suggested by Dawson et al. (2017) and Maxwell et al. (2011) for Gabon and the Republic of Congo. The marine protected area should have restrictions for the shrimp trawl fishery during the peak of the olive ridley nesting season (December to March), as well as for marine construction activities like drilling, piledriving, and dredging.

\subsection{Post-nesting directional movements}

The results of the present study enhance the catalog of post-reproductive movements recorded by Silva et al. (2011) with new records of transoceanic migrations to West Africa and to the S/SE neritic waters of Brazil and suggest an overlap with the use area of olive ridleys nesting in French Guiana (Plot et al. 2015, Chambault et al. 2016). The movements show a remarkable overlap with areas of intense fishing effort, especially for the oceanic directional movements to west Africa, where 7 of 19 turtles stopped transmitting locations. This corroborates the concerns of Silva et al. (2011) regarding the impacts of fisheries bycatch. The region has also been characterized as a high fishing pressure area for leatherbacks (Fossette et al. 2014), including bycatch of juveniles, possibly coming from west African nesting beaches (Lopez-Mendilaharsu at al. 2019), which also supports the importance of bycatch reduction measures being implemented in this area.

The use of oceanic and coastal areas by Brazil's olive ridleys was also suggested by Petitet \& Bugoni (2017), based on stable isotopes analyses, and is now confirmed by this study. The plasticity of olive ridleys' post-reproductive behaviors, when considering distinct breeding grounds around the globe, is remarkable. In the Eastern Tropical Pacific, olive ridleys display oceanic nomadic movements, without defined foraging areas (Swimmer et al. 2009, Plotkin 2010); similar patterns have been recorded in Africa, mainly along Angola's exclusive economic zone (Maxwell et al. 2011, Pikesley et al. 2013), and off India (Ram et al. 2009). In Australia, post-reproductive movements are mainly neritic, using distinct portions of the continental shelf, including the slope (McMahon et al. 2007, Whiting et al. 2007). Similar behavior has been recorded for turtles nesting in French Guiana (Plot et al. 2015, Chambault et al.
2016) and Oman (Rees et al. 2012). In Brazil, the drivers of a mixed strategy are unclear and merit further investigation. Among the available techniques, an evaluation of the movements recorded here against Lagrangian drifters or virtual particle trajectories models, is recommended (Scott et al. 2014, Hays 2017, van Sebille et al. 2018).

The olive ridley movements along the continental shelf of Brazil suggest a migratory corridor. This corridor is used by olive ridleys throughout the year after leaving or returning to the nesting beaches in Sergipe and northern Bahia, complicating conservation of this species along the several thousandkilometer journey.

Remigration to the nesting area was partially recorded for 1 olive ridley (PTT 140732, see Fig. S2 in Supplement 1) that foraged in SE Brazil, with a total track duration close to $1 \mathrm{yr}$ (337 d). The return track was similar to the post-nesting movement, which reinforces the hypothesis of a migratory corridor along the Brazilian continental shelf. The importance of Brazil's continental shelf as a migratory corridor has also been reported for loggerhead, hawksbill, and green turtles (Marcovaldi et al. 2010, 2012, Baudouin et al. 2015).

Hays \& Scott (2013) proposed that for cheloniid turtles, breeding and feeding areas should be limited to distances of less than $3000 \mathrm{~km}$ apart based on physiological limitations. However, here we have recorded greater distances for the oceanic migrations for olive ridleys (averages of $4500 \mathrm{~km}$ in directional movement and $3100 \mathrm{~km}$ in straight line distance). Hays \& Scott (2013) also stated that for leatherbacks and juvenile cheloniids, feeding during their movement limits dispersion to factors such as thermal niches or currents. Considering the distance and the duration of migrations recorded here (approximately $4500 \mathrm{~km}$ in $110 \mathrm{~d}$ ), it is plausible that some foraging is occurring during oceanic movements for these olive ridleys.

Interestingly, our results showed that variation in post-nesting migration has a relationship with animal size and seasonality. The larger olive ridleys (mean CCL: $74.9 \pm 2.7 \mathrm{~cm}$ ) captured on the nesting beaches during summer migrated to neritic foraging grounds in the south and southeast of Brazil. Smaller olive ridleys (mean CCL: $68.9 \pm 2.5 \mathrm{~cm}$ ) with oceanic migration behavior were observed nesting throughout the year. An intermediate class size (mean CCL: $70.3 \pm$ $2.7 \mathrm{~cm}$ ) used neritic areas in the north and NE of Brazil. Similar behavioral dichotomy was also observed for loggerheads that nest in Japan (Hatase et al. 2002) and Cape Verde (Hawkes et al. 2006), with larger animals feeding in neritic areas, and smaller 
animals in the open ocean. The authors proposed that the size variation may be related to dietary distinctions and nutritional characteristics of different food sources (Hawkes et al. 2006), the recruitment and settlement of the immature loggerheads (Hatase et al. 2002), and an increased probability over time for the turtle to find and re-settle in a more productive shelf area (Eder et al. 2012).

Another possible determining factor for the dichotomy of olive ridley behaviors in Brazil is the seasonality of the coastal/oceanic currents. The importance of currents for sea turtle dispersal and migratory routes was proposed by Hays et al. (2010) and Scott et al. (2014), and for early stages of sea turtle life by Putman \& Mansfield (2015). Variations in the bifurcation of the South Equatorial Current (biSEC), and in the origin of the Western Boundary Brazil and North Brazil currents (Stramma \& England 1999, Silveira et al. 2000, Amorim et al. 2011, Pereira et al. 2014) appear to be related to the north and south dispersion patterns recorded for loggerhead turtles in Brazil (Mansfield et al. 2017). As the biSEC generally occurs between $10^{\circ}$ and $14^{\circ} \mathrm{S}$ (Rodrigues et al. 2007), olive ridley hatchlings leaving Sergipe nesting beaches are exposed to seasonally varying ocean current conditions.

\subsection{Foraging ARMs}

In general, the olive ridley post-nesting movements observed here ended in areas that can be characterized as high primary productivity, either due to the presence of either upwelling systems (oceanic and southeast coast of Brazil) or neritic mud bottoms (southeast Brazil). The association of olive ridley foraging areas with higher productivity zones was previously recorded for olive ridleys, either for those located on the continental shelf (Whiting et al. 2007, Plot et al. 2015, Chambault et al. 2016) or related to oceanographic fronts, eddies, and upwelling (Ram et al. 2009, Swimmer et al. 2009, Plotkin 2010, Pikesley et al. 2013). The oceanic foraging areas off west Africa showed high primary productivity values when close to the continental slope and are also used by loggerheads that nest in Cape Verde, which illustrates the importance of the area for different species and populations of sea turtles (Hawkes et al. 2006).

Many of the areas highlighted as important for olive ridley sea turtles in this study are heavily impacted by fisheries. The oceanic portions of migratory movements, as well the inferred foraging grounds in west Africa, are associated with high levels of pelagic long-lining (Sales et al. 2008, Fossette et al. 2014).
Foraging grounds in SE Brazil overlap with an industrial bottom trawl fishery that has the sixth highest rate (relative to effort) of incidental capture of sea turtles globally (Guimarães et al. 2018). If these areas remain poorly protected, it is possible that they could act as population sinks, negating positive initiatives being undertaken elsewhere in Brazil and the wider Atlantic.

\section{FINAL CONSIDERATIONS}

The dispersion patterns identified for Lepidochelys olivacea that nest in Brazil suggest that conservation actions must consider that significant variation in the ecology of a species can occur in the same nesting area, as well as at the national and international level.

Among the identified high-use areas, the SE foraging ground, as well as the inter-nesting area, may represent opportunities for the implementation or expansion of marine protected areas. The use of satellite telemetry data to confirm or reshape marine protected areas was reviewed by Hays et al. (2019), and some examples cited are Gabon (Maxwell et al. 2011, Casale et al. 2017, Dawson et al. 2017), Mexico (Méndez et al. 2013, Cuevas et al. 2018), and Indonesia (Hitipeuw et al. 2007). In Brazil, such a measure would effectively contribute to surpassing the Aichi Biodiversity Targets (Convention on Biological Diversity). Another action could be the update of the Joined Normative Instruction No. 1, of 27 May 2011, which established restrictive measures for activities such as pipeline construction, drilling, and seismic research. The act could be revised, and the protective measures extended for the new high use areas identified here and dredging activities added to its scope.

In SE Brazil, the suggested measures could benefit a set of threatened species in addition to olive ridleys, such as fish (Epinephelus itajara, Lutjanus cyanopterus, Scarus trispinosus), rays (Manta birostris, Dasyatis centroura), guitarfishes (Zapteryx brevirostris), the shark Carcharhinus longimanus (Luiz et al. 2008), and one of the main foraging areas in Brazil for Bryde's whale Balaenoptera edeni (Gonçalves 2006).

To counteract fisheries bycatch in the inter-nesting area, one possibility would be seasonal closures for shrimp trawling. The closures should include the months of December through March, which represent the peak of the olive ridley nesting season. Also, the use of turtle excluder devices should be encouraged through monitoring and training programs, and potentially made mandatory, wherever a high-use area overlaps with shrimp trawl effort. 
In oceanic areas, despite the considerable complexity in implementing protection measures for the variety of fishery types and fleet nationalities, a viable alternative is the use of circular hooks, which have shown evidence of bycatch reduction, as well as reduction in the severity of the injuries caused (Sales et al. 2010), or restrictions on the use of surface longlines shallower than $100 \mathrm{~m}$ (Polovina et al. 2004). Another option is to create an app or website, similar to the TurtleWatch tool, that integrates bycatch data, turtle tracks, and sea surface monitoring, to inform fleets about fishing areas that must be avoided, based on sea turtle habitat characteristics (Howell et al. 2008).

Acknowledgements. This study was commissioned by the General Coordination of Oil and Gas (CGPEG), which includes the Brazilian Institute of Environment and Renewable Resources (IBAMA), as a condition of environmental licensing. We thank them for the opportunity to perform this research. We also thank the seismic research companies Geo-Petroleum Services (PGS) and Spectrum Geo Brasil for the opportunity to develop this work and examine aspects of the life cycle of sea turtles. We are also grateful to the reviewers whose comments and suggestions improved the manuscript. Projeto TAMAR, a conservation program of the Brazilian Ministry of the Environment, is affiliated with ICMBio (the Brazilian Institute for Biodiversity Conservation - Instituto Chico Mendes), co-managed by Fundação PróTAMAR, and officially sponsored by Petrobrás. Data collection by TAMAR was authorized by ICMBio, through special license number 42477-3, issued by the Biodiversity Authorization and Information System (SISBIO).

\section{LITERATURE CITED}

Abreu-Grobois FA, Plotkin P (2008) Lepidochelys olivacea. In: IUCN 2010. IUCN Red List of Threatened Species. e.T11534A3292503 Version 2017. http://dx.doi.org/ 10.2305/IUCN.UK.2008.RLTS.T11534A3292503.en

Amorim F, Cirano M, Soares I, Lentini C (2011) Coastal and shelf circulation in the vicinity of Camamu Bay $\left(14^{\circ} \mathrm{S}\right)$, Eastern Brazilian Shelf. Cont Shelf Res 31:108-119

Balazs GH (1999) Factors to consider in the tagging of sea turtles. In: Eckert KE, Bjorndal KA, Abreu-Grobois FA, Donnelly M (eds) Research and management techniques for the conservation of sea turtles. IUCN/SSC Marine Turtle Specialist Group Publication 4. IUCN/SSC, Washington, DC, p 1-10

Barraquand F, Benhamou S (2008) Animal movements in heterogeneous landscapes: identifying profitable places and homogeneous movement bouts. Ecology 89:3336-3348

Baudouin M, de Thoisy B, Chambault P, Berzins R and others (2015) Identification of key marine areas for conservation based on satellite tracking of post-nesting migrating green turtles (Chelonia mydas). Biol Conserv 184: 36-41

Behrenfeld MJ, Falkowski PG (1997) Photosynthetic rates derived from satellite-based chlorophyll concentration. Limnol Oceanogr 42:1-20
Breed GA, Jonsen ID, Myers RA, Bowen WD, Leonard ML (2009) Sex-specific, seasonal foraging tactics of adult grey seals (Halichoerus grypus) revealed by state-space analysis. Ecology 90:3209-3221

Bryant E (2007) 2D Location accuracy statistics for Fastloc Cores Running Firmware Versions 2.2 \& 2.3. Wildtrack Telemetry Systems Ltd, Redmond, WA

* Calenge C (2006) The package adehabitat for the R software: a tool for the analysis of space and habitat use by animals. Ecol Model 197:516-519

Casale P, Abitsi G, Aboro M, Agamboue P and others (2017) A first estimate of sea turtle bycatch in the industrial trawling fishery of Gabon. Biodivers Conserv 26: 2421-2433

Chambault P, de Thoisy B, Heerah K, Conchon A and others (2016) The influence of oceanographic features on the foraging behavior of the olive ridley sea turtle Lepidochelys olivacea along the Guiana coast. Prog Oceanogr 142:58-71

Coyne MS, Godley BJ (2005) Satellite Tracking and Analysis Tool (STAT): an integrated system for archiving, analyzing and mapping animal tracking data. Mar Ecol Prog Ser 301:1-7

Cuevas E, Guzmán-Hernández V, Uribe-Martínez A, Raymundo-Sánchez A, Herrera-Pavon R (2018) Identification of potential sea turtle bycatch hotspots using a spatially explicit approach in the Yucatan Peninsula, Mexico. Chelonian Conserv Biol 17:78-93

* Dawson TM, Formia A, Agamboué PD, Asseko GM and others (2017) Informing marine protected area designation and management for nesting olive ridley sea turtles using satellite tracking. Front Mar Sci 4:312

Dominguez J, Silva R, Nunes A, Freire A (2013) The narrow, shallow, low-accommodation shelf of central Brazil: sedimentology, evolution, and human uses. Geomorphology 203:46-59

* Douglas DC, Weinzierl R, Davidson CS, Kays R, Wikelski M, Bohrer G (2012) Moderating Argos location errors in animal tracking data. Methods Ecol Evol 3:999-1007

*Eder E, Ceballos A, Martins S, Pérez-García H, Marin I, Marco A, Cardona L (2012) Foraging dichotomy in loggerhead sea turtles Caretta caretta off northwestern Africa. Mar Ecol Prog Ser 470:113-122

ESRI (Environmental Systems Research Institute) (2014) ArcGIS desktop, Release 10.3. ESRI, Redlands, CA

Fontes LC, Kowsmann RO, Puga-Bermabeu A (2017) Geologia e geomorfologia da Bacia de Sergipe-Alagoas. Ed. UFS, São Cristóvão

Fossette S, Witt MJ, Miller P, Nalovic MA and others (2014) Pan-Atlantic analysis of the overlap of a highly migratory species, the leatherback turtle, with pelagic longline fisheries. Proc R Soc B 281:20133065

* Godley BJ, Blumenthal JM, Broderick AC, Coyne MS, Godfrey MH, Hawkes LA, Witt MJ (2008) Satellite tracking of sea turtles: Where have we been and where do we go next? Endang Species Res 4:3-22

Goldberg DW, de Almeida DT, Tognin F (2015) Hopper dredging impacts on sea turtles on the northern coast of Rio de Janeiro State, Brazil. Mar Turtle Newsl 147:16-20

Gonçalves LR (2006) Ocorrência, distribuição e comportamento de baleias-de-Bryde em zona costeira e oceânica do sudeste do Brasil. MSc thesis, Universidade Federal de Juiz de Fora

Gopi GV, Pandav B (2006) Incidental capture and mortality of olive ridley turtles (Lepidochelys olivacea) in commer- 
cial trawl fisheries in coastal waters of Orissa, India. Chelonian Conserv Biol 5:276-280

Guimarães SM, Tavares DC, Monteiro-Neto C (2018) Incidental capture of sea turtles by industrial bottom trawl fishery in the Tropical South-western Atlantic. J Mar Biol Assoc UK 98:1525-1531

Hamel M, McMahon C, Bradshaw C (2008) Flexible internesting behaviour of generalist olive ridley turtles in Australia. J Exp Mar Biol Ecol 359:47-54

Hart KM, Lamont MM, Sartain AR, Fujisaki I, Stephens BS (2013) Movements and habitat-use of loggerhead sea turtles in the northern Gulf of Mexico during the reproductive period. PLOS ONE 8:e66921

*Hatase H, Takai N, Matsuzawa Y, Sakamoto W and others (2002) Size-related differences in feeding habitat use of adult female loggerhead turtles Caretta caretta around Japan determined by stable isotope analyses and satellite telemetry. Mar Ecol Prog Ser 233:273-281

Hawkes LA, Broderick AC, Coyne MS, Godfrey MH (2006) Phenotypically linked dichotomy in sea turtle foraging requires multiple conservation approaches. Curr Biol 16: 990-995

Hays GC (2017) Ocean currents and marine life. Curr Biol 27:R470-R473

Hays GC, Scott R (2013) Global patterns for upper ceilings on migration distance in sea turtles and comparisons with fish, birds and mammals. Funct Ecol 27:748-756

*Hays GC, Fossette S, Katselidis KA, Mariani P, Schofield G (2010) Ontogenetic development of migration: Lagrangian drift trajectories suggest a new paradigm for sea turtles. J R Soc Interface 7:1319-1327

Hays GC, Bailey H, Bograd SJ Bowen WD and others (2019) Translating marine animal tracking data into conservation policy and management. Trends Ecol Evol 34:459-473

* Hitipeuw C, Dutton PH, Benson S, Thebu J, Bakarbessy J (2007) Population status and internesting movement of leatherback turtles, Dermochelys coriacea, nesting on the northwest coast of Papua, Indonesia. Chelonian Conserv Biol 6:28-36

*Howell EA, Kobayashi DR, Parker DM, Balazs G, Polovina JJ (2008) TurtleWatch: a tool to aid in the bycatch reduction of loggerhead turtles Caretta caretta in the Hawaiibased pelagic longline fishery. Endang Species Res 5: 267-278 doi: 10.3354/esr00096

Jeffers VF, Godley BJ (2016) Satellite tracking in sea turtles: How do we find our way to the conservation dividends? Biol Conserv 199:172-184

Jonsen ID, Mills-Flemming J, Myers RA (2005) Robust state-space modeling of animal movement data. Ecology 86:2874-2880

Kroodsma DA, Mayorga J, Hochberg T, Miller NA and others (2018) Tracking the global footprint of fisheries. Science 359:904-908

Lopez-Mendilaharsu M, Sales G, Coluchi R, Marcovaldi MÂ, Giffoni B (2019) At-sea distribution of juvenile leatherback turtles: new insights from bycatch data in the Atlantic Ocean. Mar Ecol Prog Ser 621:199-208

* Luiz O Jr, Carvalho-Filho A, Ferreira CE, Floeter SR, Gasparini J, Sazima I (2008) The reef fish assemblage of the Laje de Santos Marine State Park, Southwestern Atlantic: annotated checklist with comments on abundance, distribution, trophic structure, symbiotic associations, and conservation. Zootaxa 1807:1-25

Mansfield KL, Mendilaharsu ML, Putman NF, Marcovaldi MAG and others (2017) First satellite tracks of South
Atlantic sea turtle 'lost years': seasonal variation in transequatorial movement. Proc R Soc B 284:20171730

*Marcovaldi MÂ, Lopez GG, Soares LS, Lima EHSM, Thomé JCA, Almeida AP (2010) Satellite-tracking of female loggerhead turtles highlights fidelity behavior in northeastern Brazil. Endang Species Res 12:263-272

*Marcovaldi MÂ, Lopez GG, Soares LS, López-Mendilaharsu M (2012) Satellite tracking of hawksbill turtles Eretmochelys imbricata nesting in northern Bahia, Brazil: turtle movements and foraging destinations. Endang Species Res 17:123-132

* Matos L, Silva A, Castilhos J, Weber M, Soares L, Vicente L (2012) Strong site fidelity and longer internesting interval for solitary nesting olive ridley sea turtles in Brazil. Mar Biol 159:1011-1019

* Maxwell SM, Breed GA, Nickel BA, Makanga-Bahouna J and others (2011) Using satellite tracking to optimize protection of long-lived marine species: olive ridley sea turtle conservation in Central Africa. PLOS ONE 6: e19905

McMahon CR, Bradshaw CJA, Hays GC (2007) Satellite tracking reveals unusual diving characteristics for a marine reptile, the olive ridley turtle (Lepidochelys olivacea). Mar Ecol Prog Ser 329:239-252

*Méndez D, Cuevas E, Navarro J, González-Garza B, Guzmán-Hernández V (2013) Rastreo satelital de las hembras de tortuga blanca Chelonia mydas y evaluación de sus ámbitos hogareños en la costa norte de la península de Yucatán, México. Rev Biol Mar Oceanogr 48: 497-509

Neves EG, Johnsson R, Sampaio CLS (2005) An unexpected coral assemblage in submerged reefs of the Sergipe state. In: Anais do II Congresso Brasileiro de Oceanografia, Vitória, ES, Brazil, p 1-2

Paes ET, Alcântara AV, Guimarães CRP, Araujo HMP, Alaves JPH (2007) Caracterização ecológica e oceanográfica da plataforma continental do estado de Sergipe: um ambiente costeiro equatorial sob influência de águas subantárticas. In: Anais do XII Congresso Latino-Americano de Ciencias do Mar - Colacmar, Florianópolis, SC, Brazil

* Pereira J, Gabioux M, Marta Almeida M, Cirano M, Paiva AM, Aguiar AL (2014) The bifurcation of the western boundary current system of the south Atlantic Ocean. Braz J Geophys 32:241-257

* Petitet R, Bugoni L (2017) High habitat use plasticity by female olive ridley sea turtles (Lepidochelys olivacea) revealed by stable isotope analysis in multiple tissues. Mar Biol 164:134

* Pikesley SK, Maxwell SM, Pendoley K, Costa DP and others (2013) On the front line: integrated habitat mapping for olive ridley sea turtles in the southeast Atlantic. Divers Distrib 19:1518-1530

* Plot V, de Thoisy B, Blanc S, Kelle L and others (2012) Reproductive synchrony in a recovering bottlenecked sea turtle population. J Anim Ecol 81:341-351

* Plot V, de Thoisy B, Georges JY (2015) Dispersal and dive patterns during the post-nesting migration of olive ridley turtles from French Guiana. Endang Species Res 26: 221-234

* Plotkin PT (2010) Nomadic behaviour of the highly migratory olive ridley sea turtle Lepidochelys olivacea in the eastern tropical Pacific Ocean. Endang Species Res 13: 33-40

* Polovina J, Balazs G, Howell E, Parker D, Seki M, Dutton P (2004) Forage and migration habitat of loggerhead 
(Caretta caretta) and olive ridley (Lepidochelys olivacea) sea turtles in the central North Pacific Ocean. Fish Oceanogr 13:36-51

Putman NF, Mansfield KL (2015) Direct evidence of swimming demonstrates active dispersal in the sea turtle 'lost years'. Curr Biol 25:1221-1227

R Core Team (2015) R: a language and environment for statistical computing. R Foundation for Statistical Computing, Vienna

Ram P, Rao S, Sadhuram Y (2009) Drifting and meandering of olive ridley sea turtles in the Bay of Bengal: role of oceanic Rossby waves. Mar Geod 32:372-378

Rees AF, Al-Kiyumi A, Broderick AC, Papathanasopoulou N, Godley BJ (2012) Conservation related insights into the behaviour of the olive ridley sea turtle Lepidochelys olivacea nesting in Oman. Mar Ecol Prog Ser 450:195-205

Rodrigues R, Rothstein L, Wimbush M (2007) Seasonal variability of the South Equatorial Current Bifurcation in the Atlantic Ocean: a numerical study. J Phys Oceanogr 37: $16-30$

Sales G, Giffoni B, Barata P (2008) Incidental catch of sea turtles by the Brazilian pelagic longline fishery. J Mar Biol Assoc UK 88:853-864

Sales G, Giffoni BB, Fiedler FN, Azevedo VG, Kotas JE, Swimmer Y, Bugoni L (2010) Circle hook effectiveness for the mitigation of sea turtle bycatch and capture of target species in a Brazilian pelagic longline fishery. Aquat Conserv 20:428-436

Santos AS, Marcovaldi MA, Sales G (eds) (2011) Plano de Ação Nacional para conservação das tartarugas marinhas. Série Espécies Ameaçadas 25. ICMBio, Brasília

Scott R, Marsh R, Hays G (2014) Ontogeny of long distance migration. Ecology 95:2840-2850

Seidel DP, Dougherty E, Carlson C, Getz WM (2018) Ecological metrics and methods for GPS movement data. Int J Geogr Inf Sci 32:2272-2293

* Silva ACCD, Castilhos JC, Lopez G, Barata PCR (2007) Nesting biology and conservation of the olive ridley sea turtle (Lepidochelys olivacea) in Brazil, 1991/1992 to 2002/2003. J Mar Biol Assoc UK 87:1047-1056

Silva ACCD, Castilhos JC, Santos EAP, Brondízio LS,

Editorial responsibility: Rebecca Lewison,

San Diego, California, USA
Bugoni L (2010) Efforts to reduce sea turtle bycatch in the shrimp fishery in Northeastern Brazil through a comanagement process. Ocean Coast Manag 53:570-576

* Silva ACCD, Santos EAP, Oliveira FLC, Weber MI, Batista JAF, Serafini TZ, Castilhos JC (2011) Satellite-tracking reveals multiple foraging strategies and threats for olive ridley turtles in Brazil. Mar Ecol Prog Ser 443:237-247

* Silveira ICA, Schmidt ACK, Campos EJD, Godoi SS, Ikeda Y (2000) The Brazil Current off the Eastern Brazilian Coast. Rev Bras Oceanogr 48:171-183

Stramma L, England M (1999) On the water masses and mean circulation of the South Atlantic Ocean. J Geophys Res 104:20863-20883

* Swimmer Y, McNaughton L, Foley D, Moxey L, Nielsen A (2009) Movements of olive ridley sea turtles Lepidochelys olivacea and associated oceanographic features as determined by improved light-based geolocation. Endang Species Res 10:245-254

Thomas A (1994) BUGS: a statistical modelling package. RTA/BCS Modular Languages Newsl 2:36-38

Turtle Expert Working Group (2009) An assessment of the loggerhead turtle population in the western North Atlantic Ocean. Tech Memo NMFS-SEFSC-575

van Sebille VE, Griffies SM, Abernathey R, Adams TP and others (2018) Lagrangian ocean analysis: fundamentals and practices. Ocean Model 121:49-75

*Whiting SD, Long JL, Coyne M (2007) Migration routes and foraging behaviour of olive ridley turtles Lepidochelys olivacea in northern Australia. Endang Species Res 3:1-9

Wikelski M, Kays R (2015) Movebank: archive, analysis and sharing of animal movement data. Hosted by the Max Planck Institute for Ornithology. www.movebank.org (accessed on 5 May 2015)

*Wilmers CC, Nickel B, Bryce CM, Smith JA, Wheat RE, Yovovich V (2015) The golden age of bio-logging: how animal-borne sensors are advancing the frontiers of ecology. Ecology 96:1741-1753

WWorton BJ (1989) Kernel methods for estimating the utilization distribution in home-range studies. Ecology 70:164-168

Zar JH (1999) Biostatistical analysis, $4^{\text {th }}$ edn. Prentice Hall, Upper Saddle River, NJ

Submitted: June 18, 2018; Accepted: August 27, 2019

Proofs received from author(s): October 28, 2019 